\title{
Beyond the Hoax: A Response to Emily A. Schultz by Alan Sokal
}

Reviews in Anthropology, vol. 40, issue 2, pp. 169-173 (April 2011)

I am grateful to the editors of Reviews in Anthropology for giving me the opportunity to respond to Emily Schultz's review (2010) of my book Beyond the Hoax: Science, Philosophy and Culture (2008). I shall begin by briefly correcting several of Schultz's misrepresentations of my ideas. I shall then endeavor to address the intellectually interesting issues that she raises.

1) Schultz (2010:322) cites me (2008:123) as quoting Donna Haraway as follows:

For the complex or boundary objects in which I am interested ... dimensions implode ... they collapse into each other ... story telling ... is a fraught practice ... In no way is story telling opposed to materiality, $[$ sic $]$ But materiality itself is tropic; it makes us swerve, it trips us; it is a knot of the textual, technical, mythic/oneric [sic], organic, political and economic.

She then takes me to task by observing that

the cited passage is riddled with ellipses. To be sure, Sokal links up subjects, verbs and objects, but the significance of their linkage is muddled because an unknown amount of potentially vital surrounding text has been excised.

The trouble is, the ellipses for which Schultz berates me are her own creation! In my book I quote the entire paragraph from Haraway (1994:63), without omitting even a single word, as follows:

For the complex or boundary objects in which I am interested, the mythic, textual, technical, political, organic, and economic dimensions implode. That is, they collapse into each other in a knot of extraordinary density that constitutes the objects themselves. In my sense, story telling is in no way an 'art practice' it is, rather, a fraught practice for narrating complexity in such a field of knots or black holes. In no way is story telling opposed to materiality. But materiality itself is tropic; it makes us swerve, it trips us; it is a knot of the textual, technical, mythic/oneiric, organic, political, and economic. [2008:123]

I would like to think that this gross misquotation is honest error, not fraudulent misrepresentation. But it is nevertheless a rather astonishing feat for a reviewer who presumably had a copy of my book in front of her as she composed her review.

2) More generally, Schultz claims repeatedly that my analytical method consists of "ripping individual passages or sentences from the texts in which they appear and holding them up to ridicule" (2010:314). But the only concrete example she gives of 
such a method is the mangled quotation from Haraway. She never mentions my detailed and respectful analyses of some key ideas from the work of Carolyn Merchant, Sandra Harding and Evelyn Fox Keller (119-129), Barry Barnes and David Bloor (203-211), and Bruno Latour (211-216), in which I explain my disagreements with their theses and my view of the kernels of truth in their contentions. Schultz could of course rightly observe that these analyses do not refute the entire œuvre of the authors in question, and I have never claimed that they do. But it would have been more interesting had Schultz actually addressed my arguments, rather than claiming falsely that I have none.

3) Schultz observes correctly that my book contains many footnotes, "sometimes taking up more space [on the page] than the main text" (2010:323). It seems to me that footnotes are a useful way of conveying subsidiary qualifications or interesting but dispensable digressions, without bogging down the main text; and it also goes without saying that each reader is free to like or dislike this style. But Schultz falsely claims that the footnotes represent recent amendments to previously published essays, condescendingly concluding (in one typical case) that my "understanding of the meaning of Collins's statement has become more nuanced over time" (2010:324). In fact, the footnote she cites (152n9 and 230n3) was present in the versions of these essays originally written in 1997 and 2001 (Sokal 1998:19n9, Sokal and Bricmont 2004:18n3), as Schultz could easily have verified by typing a few words into Google Books. More fundamentally, her complaint with this footnote is bizarre, and in flat contradiction with her contention that my main method is "ridicule". Sociologist of science Harry Collins (1981:3) made the rather astonishing assertion that "the natural world has a small or non-existent role in the construction of scientific knowledge". Rather than simply pointing out the manifest falsity of this statement when the words in it are given their natural and unambiguous meanings, I bent over backwards in the footnote to come up with some charitable interpretations of what Collins might be trying inarticulately to say. Likewise for the footnote (237n28) concerning Quine's radical-sounding assertion that "any statement can be held true come what may" (Quine 1980:43) - a footnote that Schultz labels as "anxious" but which could equally well be described as "bending over backwards to be generous".

4) Schultz snootily dismisses my examination of postcolonial and Hindu-nationalist conceptions of science (297-321) as "twenty pages of sound-bite analysis" (2010:326) - a clever put-down, to be sure, but one that she does not deign to substantiate with any precise criticisms. I leave it to readers to judge my arguments for themselves. More importantly, Schultz chastises me for allegedly "evaluating the views of scholars and theorists not on their own merits, but according to the purported ease with which they give aid and comfort to the enemy" (2010:326). This would be a valid criticism were that indeed my method, but in fact I say quite explicitly the exact opposite:

Of course, if a theory is supported by cogent reasoning or persuasive empirical evidence, then it is unfair to criticize it on the grounds that it may lead, in some people's hands, to bad consequences; rather, it is the misuse of a valid idea that 
should be criticized instead. But if a doctrine is based on sloppy reasoning as I believe postmodernism is ${ }^{261}$ - then it is not out of place to observe that it can also have pernicious consequences. $[2008: 343]^{1,2}$

My next and primary task should now be to address Schultz's substantive criticisms of my book. The trouble is, there are none to speak of: Schultz does not address much less refute - any of the principal arguments that I make in any part of my book. There is only a confused comment concerning Quinean underdetermination (2010:325) and an even more bizarre paragraph seguing from Ashis Nandy to interdisciplinarity $(2010: 336-7) .{ }^{3}$ This is a shame: I would very much welcome rigorous criticism of my arguments concerning epistemology, pseudoscience and religion. But that, alas, will have to await another review and another reviewer.

\section{References Cited}

Bricmont, Jean and Alan D. Sokal. 2001. Science and sociology of science: Beyond war and peace. In: The One Culture?: A Conversation about Science, edited by Jay Labinger and Harry Collins, pp. 27-47, 179-183 and 243-254. Chicago: University of Chicago Press.

\footnotetext{
${ }^{1}$ Footnote 261 reads as follows: "The degree of validity of postmodernist ideas is, of course, a vast issue that goes far beyond the scope of this essay. It becomes particularly thorny because of the great diversity of ideas that go under the name of 'postmodernism' (even within my rather restrictive definition [given earlier on pp. 269-271]). Some of my views on these matters can be found in Chapters 6 and 7 above, as well as in Sokal and Bricmont (1998, chapter 12). See also Haack (1998, 2003), Brown (2001) and Nanda (2003) for cogent critiques of postmodernist philosophical doctrines."

${ }^{2}$ See also 2008:374: "[W] hen discussing any set of ideas, it is important to distinguish between the intrinsic merit of those ideas, the objective role they play in the world, and the subjective reasons for which various people defend or attack them." And see Bricmont and Sokal (2001:182): "[W]e do not judge ideas according to their real or alleged 'consequences', nor according to the real or alleged motivations of their advocates or detractors, nor according to the real or alleged moral worth of the social groups in which they are popular or unpopular. Our objection to the strong programme in the sociology of science] is that we think it is philosophically and methodologically misguided, not that it is harmful to the public image of science."

${ }^{3}$ For what it's worth, Schultz completely misunderstands Bricmont's and my discussion of Quinean underdetermination (2008:235-7), getting it exactly backwards. Far from attempting "to refute the thesis of the under-determination of theory by evidence" (2010:325), as she thinks, we argue that radical underdetermination is real but principally concerns what we call "crazy theories", of which we give several examples (2008:236).

There is, in fact, a real gap in our treatment of Quinean underdetermination, though Schultz misses it. What criteria can be used to distinguish between "crazy" and "non-crazy" theories? This is a very important problem in the philosophy of science, to which most workers in the field (including Bricmont and myself) have paid insufficient attention. My current view is that the best solution will involve a hierarchy of metaphysical working hypotheses, roughly along the lines proposed by Nicholas Maxwell (1998).
} 
Brown, James Robert. 2001. Who Rules in Science?: An Opinionated Guide to the Wars. Cambridge, Mass.: Harvard University Press.

Collins, Harry M. 1981. Stages in the empirical programme of relativism. Social Studies of Science 11: 3-10.

Haack, Susan. 1998. Manifesto of a Passionate Moderate: Unfashionable Essays. Chicago: University of Chicago Press.

Haack, Susan. 2003. Defending Science - Within Reason: Between Scientism and Cynicism. Amherst, N.Y.: Prometheus Books.

Haraway, Donna J. 1994. A game of cat's cradle: Science studies, feminist theory, cultural studies. Configurations: A Journal of Literature, Science, and Technology 2: 59-71.

Maxwell, Nicholas. 1998. The Comprehensibility of the Universe: A New Conception of Science. Oxford: Clarendon.

Nanda, Meera. 2003. Prophets Facing Backward: Postmodern Critiques of Science and Hindu Nationalism in India. New Brunswick, N.J.: Rutgers University Press.

Quine, Willard Van Orman. 1980. Two dogmas of empiricism. In: From a Logical Point of View, 2nd ed. revised. [1st ed. 1953] Cambridge, Mass.: Harvard University Press.

Schultz, Emily A. 2010. Fear of scandalous knowledge: Arguing about coherence in scientific theory and practice. Reviews in Anthropology 39: 313-343.

Sokal, Alan. 1998. What the Social Text affair does and does not prove. In: A House Built on Sand: Exposing Postmodernist Myths About Science, edited by Noretta Koertge, pp. 9-22. New York: Oxford University Press.

Sokal, Alan. 2008. Beyond the Hoax: Science, Philosophy and Culture. Oxford: Oxford University Press.

Sokal, Alan and Jean Bricmont. 1998. Fashionable Nonsense: Postmodern Intellectuals' Abuse of Science. New York: Picador USA. [Published in the U.K. under the title Intellectual Impostures: Postmodern Philosophers' Abuse of Science. London: Profile Books, 1998. Originally published in French under the title Impostures intellectuelles. Paris: Odile Jacob, 1997.]

Sokal, Alan and Jean Bricmont. 2004. Defense of a modest scientific realism. In: Knowledge and the World: Challenges Beyond the Science Wars (Proceedings of the BielefeldZiF conference, 18-20 June 2001), edited by Martin Carrier, Johannes Roggenhofer, Günter Küppers and Philippe Blanchard, pp. 17-45. Berlin-Heidelberg: Springer-Verlag. 


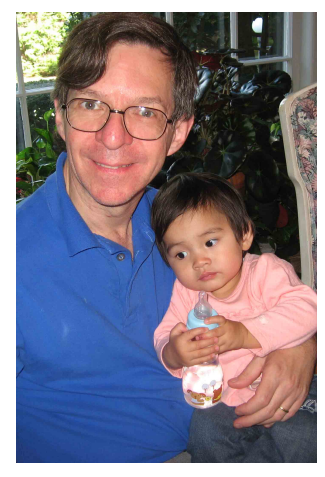

ALAN SOKAL (left) is Professor of Physics at New York University and Professor of Mathematics at University College London. 